Journal of Animal and Veterinary Advances 11 (16): 2976-2979, 2012

ISSN: $1680-5593$

(C) Medwell Journals, 2012

\title{
Non-Starch Polysaccharides (NSP) Enzyme Improves the Nutrient Digestibility of Weaned Piglet Fed a Cottonseed Meal-Based Diets
}

\author{
${ }^{1,2}$ Wang Shengping, ${ }^{1}$ Jun Fang, ${ }^{2}$ Tang Xiangshan, ${ }^{1}$ Wang Jie, ${ }^{3}$ Zhichun Zhan, ${ }^{3}$ Ying Zhou, \\ ${ }^{4} \mathrm{Xiaosong} \mathrm{Wu},{ }^{5}$ Dingding Su, ${ }^{2} \mathrm{Gang} \mathrm{Liu},{ }^{6} \mathrm{Jiannan}$ Ding and ${ }^{6}$ Lichuang Cai \\ ${ }^{1}$ College of Biotechnology, Hunan Agricultural University, 410128 Changsha, Hunan, China \\ ${ }^{2}$ Key Laboratory of Agro-Ecological Processes in Subtropical Region, \\ Chinese Academy of Sciences, Institute of Subtropical Agriculture, \\ Hunan Provincial Engineering Research Center of Healthy Livestock, \\ Scientific Observing and Experimental Station of Animal Nutrition and \\ Feed Science in South-Central, Ministry of Agriculture, Changsha, 410125 Hunan, China \\ ${ }^{3}$ Wuhan Sunhy Biology Co. Ltd., Wuhan, 430070 Hubei, China \\ ${ }^{4}$ College of Animal Science and Technology, Hunan Agricultural University, \\ 410128 Changsha, Hunan, China \\ ${ }^{5}$ Hunan Provincial Key Laboratory for Germplasm Innovation and Utilization of Crop, \\ 410128 Changsha, China \\ ${ }^{6}$ Jiangxi Academy of Sciences, Biological Resources Institute, Nanchang, \\ 330029 Jiangxi, P.R. China
}

\begin{abstract}
NSP is the major factor introducing a low digestibility of cottonseed meal in piglets. The present study was conducted to determine the effect of NSP enzyme on the nutrient digestibility of weaned piglets fed a cottonseed meal-based diets. About 15 weaned piglets $(14 \pm 1.4 \mathrm{~kg})$ were selected and ileal fistula surgery was done to determine the DE, CP, DM and NSP's apparent digestibility. The results indicated that NSP enzyme improved piglet's apparent digestibility $(\mathrm{p}<0.05)$ in varying degrees; pectinase resulted in obvious degradation of the cell wall and increased piglets' DE (26.69\%) and CP of ileal digesta (20.33\%) and compound enzyme was better in improving cottonseed meal based diets than single enzyme.
\end{abstract}

Key words: Cottonseed meal, NSP enzyme, piglets, apparent digestibility, surgery, degradation

\section{INTRODUCTION}

Fibre is resistant to digestion by endogenous enzymes in mammals and it will decrease the digestibility of feed nutrients and increase endogenous protein and fat losses (Noblet and Perez, 1993; Delange et al., 1989). Dietary fibre, particularly soluble Non-Starch Polysaccharides (NSP) has high water-binding capacity (Antoniou and Marquardt, 1981; Jensen and Jorgensen, 1994; Yin et al., 1994; Bach Knudsen, 2001; Yin and Tan, 2010). Thus, the nutrition is not easy to be absorbed, because the complexes of NSP and water wrap the nutrition and prevent the enzyme digestion on feed. NSP is the major composition of cell wall and is hard to degraded by enzyme which results in the limit in digestion of enzyme on feed (Hesselman and Aman, 1986; Aman et al., 1989; Bedford and Classen, 1992; Yin et al., 2001a-d). Some studies found that the content of SNSP in diet influenced the AME of diet (Leclere et al., 1993) and there was a negative correlation between the content of SNSP in diet and the AME of diet.
Cottonseed meal is a good protein feed and has been widely used as feed ingredient (Yin et al., 1993). However, the high content of NSP limits its application in feed industry. Thus, researchers conducted a study to determine the impact of soluble NSP enzymes on cottonseed meal's digestibility in pig.

\section{MATERIALS AND METHODS}

Piglets and treatments: Twenty seven Duroc $x$ Landrace $\mathrm{x}$ Yorkshire weaned piglets (Hunan GuangAn BioTechnology Company) feed the basal diet (Table 1) were selected and had fully slatted floors, nipple drinkers and electronic feeding stations according to the methods of Yao et al. (2008) and Deng et al. (2009). These piglets were kept in single crates and were assigned to 9 treatments ( 3 sows per treatment). After 7 days, these piglets were executed ileum-fistula surgery and conducted 40 days experiment. NSP enzymes were provided by Wuhan new HUAYANG feed Co., Ltd. (WuHan city, China).

Corresponding Author: Jun Fang, College of Biotechnology, Hunan Agricultural University, 410128 Changsha, Hunan, China 
Table 1: Composition of basal diet

\begin{tabular}{llllllll}
\hline Diet & Starch & Cottonseed meal & Soy oil & Sugar & $\mathrm{CaHCO}_{3}$ & $\mathrm{CaCO}_{3}$ & Total \\
\hline Ratio (\%) & 37.2 & 45 & 2 & 10 & 1 & 1 & 100 \\
Diet & Acidifier & $\mathrm{NaCl}$ & $\mathrm{TiO}_{2}$ & Vitamin & Minerals & Choline chloride & - \\
Ratio (\%) & 2 & 0.3 & 0.1 & 0.3 & 1 & 0.1 & - \\
\hline
\end{tabular}

Sampling procedures: The collected digesta were freeze-dried for one weak in freeze-drying machine. The energy, Crude Protein (CP), NSP, Titanium dioxide and amino acids of digesta and feed were determined. CP was determined by the Kjeldahl Nitrogen Determination Method. Energy was determined by adiabatic calorimeter. Titanium dioxide was determined by spectrophotography according to Yin et al. (2000). Amino acids were determined by $₫ \mathrm{~N}$ Hydrochloric Acid Hydrolysis Method according to Huang et al. (2005) as:

Apparent nutrient digestibility (\%)

$=\frac{1 \text {-nurtient content in digesta } \times \mathrm{TiO}_{2} \text { content in feed }}{\text { Nutrient content in feed } \times \mathrm{TiO}_{2} \text { content in digesta }} \times 100 \%$

Statistical analyses: Values are presented as the mean \pm SD. All data were analyzed using one-way ANOVA (SAS Institute, NC, USA). Duncan's multiple range test was used to compare differences among the treatment groups. Probability values $\mathrm{p}<0.05$ were taken to indicate statistical significance (He et al., 2012).

\section{RESULTS AND DISCUSSION}

The influence on dry matter apparent digestibility of different NSP enzymes: The results indicated that supplementation with NSP enzymes in cottonseed meal diet can improve dry matter apparent digestibility ( $<<0.05$ ) (Fig. 1). The Treatment 5 (supplementation with pectinase) got the best effect among all treatments, improved the dry matter apparent digestibility by $28 \%$. Generally, supplementation with combination of different enzymes in diet is better than supplementation with single enzyme.

The influence on energy apparent digestibility of different NSP enzymes: The results indicated that supplementation with NSP enzymes in cottonseed meal diet can improve energy apparent digestibility $(\mathrm{p}<0.05)$ (Fig. 2). The Treatment 5 (supplementation with pectinase) got the best effect among all treatments, improved the dry matter apparent digestibility by $26.69 \%$. However, supplementation with combination of different enzymes in diet is no better than supplementation with single enzyme $(\mathrm{p}>0.05)$.



Fig. 1: Effects of adding multi-enzyme on the AD of DM. ${ }^{\mathrm{a}-\mathrm{d}}$ Means within each column with no common superscript differ at $\mathrm{p}<0.05$

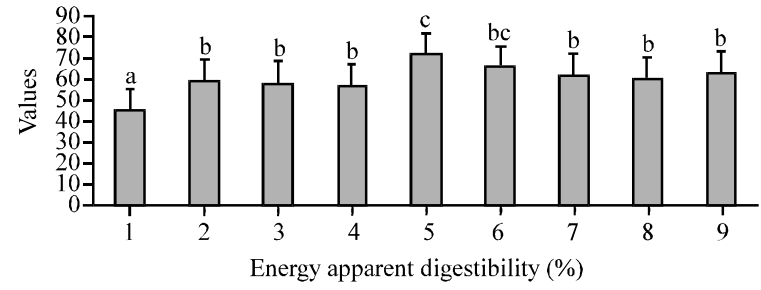

Fig. 2: Effects of adding multi-enzyme on the ADE. a-cMeans within each column with no common superscript differ at $\mathrm{p}<0.05$



Fig. 3: Effects of adding multi-enzyme on the AD of CP. ${ }^{\mathrm{a}-\mathrm{d}}$ Means within each column with no common superscript differ at $\mathrm{p}<0.05$

The influence on crude protein apparent digestibility of different NSP enzymes: The results indicated that supplementation with NSP enzymes in cottonseed meal diet can improve crude protein apparent digestibility $(\mathrm{p}<0.05) \quad$ (Fig. 3). The Treatment 5 (supplementation with pectinase) got the best effect among all treatments, improved the dry matter apparent digestibility by $20.33 \%$. Generally, supplementation with combination of different enzymes in diet is slightly better than supplementation with single enzyme $(\mathrm{p}<0.05)$. 
Table 2: Effects of adding multi-enzyme on the AD of SNSP

\begin{tabular}{lllllll}
\hline Treatments & Arabinose & Xylan & Manna & Galactose & Glucose & Total SNSP \\
\hline 1 & $24.50 \pm 1.39^{\mathrm{a}}$ & $08.47 \pm 0.97^{\mathrm{a}}$ & $38.68 \pm 1.11^{\mathrm{a}}$ & $09.68 \pm 0.25^{\mathrm{a}}$ & $79.06 \pm 0.28^{\mathrm{a}}$ & $43.90 \pm 0.74^{\mathrm{a}}$ \\
2 & $54.89 \pm 1.02^{\mathrm{b}}$ & $43.85 \pm 0.94^{\mathrm{e}}$ & $42.37 \pm 0.99^{\mathrm{b}}$ & $33.50 \pm 1.29^{\mathrm{d}}$ & $80.86 \pm 0.64^{\mathrm{b}}$ & $61.61 \pm 0.81^{\mathrm{d}}$ \\
3 & $33.80 \pm 0.65^{\mathrm{b}}$ & $23.48 \pm 0.98^{\mathrm{b}}$ & $61.05 \pm 0.96^{\mathrm{e}}$ & $19.05 \pm 1.02^{\mathrm{b}}$ & $86.04 \pm 0.65^{\mathrm{d}}$ & $54.52 \pm 0.60^{\mathrm{b}}$ \\
4 & $41.23 \pm 1.20^{\mathrm{e}}$ & $30.79 \pm 1.62^{\mathrm{c}}$ & $47.92 \pm 1.08^{\mathrm{c}}$ & $41.93 \pm 1.27^{\mathrm{e}}$ & $90.04 \pm 0.44^{\mathrm{ef}}$ & $62.48 \pm 0.65^{\mathrm{de}}$ \\
5 & $60.29 \pm 0.06^{\mathrm{h}}$ & $31.61 \pm 0.41^{\mathrm{c}}$ & $49.50 \pm 1.42^{\mathrm{c}}$ & $48.14 \pm 0.82^{\mathrm{f}}$ & $83.10 \pm 0.76^{\mathrm{c}}$ & $64.57 \pm 0.31^{\mathrm{f}}$ \\
6 & $38.17 \pm 0.83^{\mathrm{c}}$ & $38.63 \pm 0.53^{\mathrm{d}}$ & $54.78 \pm 0.74^{\mathrm{d}}$ & $28.67 \pm 0.61^{\mathrm{c}}$ & $86.50 \pm 0.36^{\mathrm{d}}$ & $57.63 \pm 0.52^{\mathrm{c}}$ \\
7 & $45.34 \pm 0.73^{\mathrm{f}}$ & $45.77 \pm 1.22^{\mathrm{e}}$ & $49.31 \pm 1.04^{\mathrm{c}}$ & $43.32 \pm 1.34^{\mathrm{e}}$ & $89.19 \pm 0.17^{\mathrm{e}}$ & $63.70 \pm 0.83^{\mathrm{ef}}$ \\
8 & $40.81 \pm 0.69^{\mathrm{de}}$ & $30.39 \pm 0.58^{\mathrm{c}}$ & $64.94 \pm 0.22^{\mathrm{f}}$ & $31.79 \pm 0.43^{\mathrm{dd}}$ & $91.14 \pm 0.24^{\mathrm{f}}$ & $61.36 \pm 0.20^{\mathrm{d}}$ \\
9 & $59.12 \pm 1.10^{\mathrm{h}}$ & $36.66 \pm 0.98^{\mathrm{d}}$ & $63.12 \pm 0.77^{\mathrm{ef}}$ & $41.33 \pm 2.46^{\mathrm{e}}$ & $91.00 \pm 0.37^{\mathrm{f}}$ & $64.73 \pm 0.66^{\mathrm{f}}$ \\
\hline
\end{tabular}

${ }^{\mathrm{a}-\mathrm{d}}$ Means within each column with no common superscript differ at $\mathrm{p}<0.05$

Table 3: The design of experiment

\begin{tabular}{lll}
\hline Groups & Enzyme & Enzyme activity $\left(\mathrm{U} \mathrm{kg}^{-1}\right)$ \\
\hline Control & Null & 0 \\
2 & Xylan & 4000 \\
3 & Mannanase & 4000 \\
4 & Glucanase & 2000 \\
5 & Pectinase & 3000 \\
6 & Xylanase + mannanase & $4000+4000$ \\
7 & Xylanase + glucanase & $4000+2000$ \\
8 & Mannanase + glucanase & $4000+2000$ \\
9 & Xylanase + mannanase + glucanase & $4000+4000+2000$ \\
\hline
\end{tabular}

The influence on SNSP apparent digestibility of different NSP enzymes: The results indicated that supplementation with NSP enzymes in cottonseed meal diet can improve SNSP apparent digestibility including arabinose, xylose, mannose, galactose and glucose $(\mathrm{p}<0.05)$ (Table 2). Based on total SNSP, Treatment 2, 3, 5, 7, 8 and 9 increased the apparent digestibility by $35.79,37.3,26.26,38.46,12.08$ and $20.83 \%$, especially.

Compared with the control group (Treatment 1), supplementation with NSP enzymes in diet can improve dry matter, energy and crude protein apparent digestibility of cottonseed meal diet which is similar to the previous studies of Ye et al. (2011).

The crude protein apparent digestibility of cottonseed meal in the present study is lower than in the other studies, even if supplemented with NSP enzymes. The possible reason is that the cottonseed meal content in diet is too high (45\%) and the cottonseed meal contains very much NSP. From Fig. 1, 2 and Table 3, Treatment 5 (supplementation with pectinase) got the best effect in CP, DM and DE apparent digestibility. Pectin is the major composition of cell wall. Pectinase maybe break down the cell wall and then the nutrient will be released from the inner.

Weaned piglets have a high glucose apparent digestibility $(79.06 \%)$ however, a low xylan and galactose apparent digestibility (Table 3). Among Treatment 2-5, xylanase can significantly improve the xylan and arabinose apparent digestibility. The improved degree is much high than no-xylanase (Table 3). Mannanase can significantly improve the mannan and glucose apparent digestibility. The improved degree is much high than other single enzyme (Table 3). Glucanse has a higher glucose apparent digestibility than other single enzyme. Pectinase improved significantly galactose and arabinose apparent digestibility and has a improvement on the other carbohydrate in a different degree. The improvement effects of pectinase on apparent digestibility are similar to combination of enzymes.

Generally, combination of enzymes is superior to single enzyme in apparent digestibility. Based on the SNSP, the highest to lowest ranking of apparent digestibility is Treatment $9,7,5,4,8,2,6,3$ and Treatment 1 .

\section{CONCLUSION}

The results indicated that NSP enzyme improved piglet's apparent digestibility $(\mathrm{p}<0.05)$ in varying degrees; pectinase resulted in obvious degradation of the cell wall and increased piglets' DE (26.69\%) and CP of ileal digesta $(20.33 \%)$. Compound enzyme was better in improving cottonseed meal-based diets than single enzyme.

\section{ACKNOWLEDGEMENTS}

The present research was supported by a grant from NSFC project (31110103909) National Basic Research Program of China (2012CB124704) the Knowledge Innovation program of the Chinese Academy of Sciences (KZCX2-EW-412; KZCX2-YW-T07; KSCX2-EW-G-16; XMXX281177), State Key Laboratory of Food Science and Technology project (SKLF-TS-201108 8), Nanchang University the Ministry of Science and Technology of the People's Republic of China (2010GB2D200322) and Hunan Provincial Natural Science Foundation of China (10JJ2028, 2011NK2011).

\section{REFERENCES}

Aman, M.G., C.J. Teehan, A.J. White, S.H. Turbott and C. Vaithianathan, 1989. Haloperidol treatment with chronically medicated residents: Dose effects on clinical behavior and reinforcement contingencies. Am. J. Ment. Retard., 93: 452-460. 
Antoniou, T. and R.R. Marquardt, 1981. Influence of rye pentosans on the growth of chicks. Poult. Sci., 60: 1898-1904.

Bach Knudsen, K.E., 2001. The nutritional significance of dietary fiber analysis. Anim. Feed Sci. Technol., 90: 3-20.

Bedford, M.R. and H.L. Classen, 1992. Reduction of intestinal viscosity through manipulation of dietary rye and pentosanase concentration is effected throughout changes in carbohydrate composition of the intestinal aqueous phase and results in improved growth rate and food conversion efficiency of broiler chicks. J. Nutr., 122: 560-569.

Delange, F., J. De Vijlder, G.M. de Escobar, P. Rochiccioli and S. Varrone, 1989. Significance of Early Diagnostic Data in Congenital Hypothyroidism: Report of the Subcommittee on Neonatal Hypothyroidism of the European Thyroid Association. In: Research in Congenital Hypothyroidism, Delange, F., D.A. Fisher and D. Glinoer (Eds.). Plenum Press, New York, NY, USA., pp: 225-234.

Deng, D., K. Yao, W.Y. Chu, T.J. Li and R.L. Huang et al., 2009. Impaired translation initiation activation and reduced protein synthesis in weaned piglets fed a low-protein diet. J. Nutr. Biochem., 20: 544-552.

He, Q., P. Ren, X. Kong, Y. Wu and G. Wu et al., 2012. Comparison of serum metabolite compositions between obese and lean growing pigs. J. Nutr. Biochem., 23: 133-139.

Hesselman, K. and P. Aman, 1986. The effect of beta glucanase on the utilization of starch and nitrogen by broiler chickens fed barley of low or high viscosity. Anim. Feed Sci. Technol., 15: 83-93.

Huang, R.L., Y.L. Yin, G.Y. Wu, Y.G. Zhang and T.J. Li et al., 2005. Effect of dietary oligochitosan supplementation on ileal digestibility of nutrients and performance in broilers. Poult. Sci., 84: 1383-1388.

Jensen, B.B. and H. Jorgensen, 1994. Effect of dietary fiber on microbial activity and microbial gas production in various regions of the gastrointestinal tract of pigs. Appl. Environm. Microb., 60: 1897-1904.

Leclere, C., D. Lairon, M. Champ and C. Cherbut, 1993. Influence of particle size and sources of non-starch polysaccharides on postprandial glycaemia, insulinaemia and triacylglycerolaemia in pigs and starch digestion In vitro. Br. J. Nutr., 70: 179-188.

Noblet, J. and J.M. Perez, 1993. Prediction of digestibility of nutrient and energy values of pig diets from chemical analysis. J. Anim. Sci., 71: 3389-3398.

Yao, K., Y.L. Yin, W. Chu, Z. Liu and D. Deng et al., 2008. Dietary arginine supplementation increases $\mathrm{mTOR}$ signaling activity in skeletal muscle of neonatal pigs. J. Nutr., 138: 867-872.
Ye, N., D. Chen, X. Mao, Z. Huang and Q. Mao et al., 2011. Xylanase supplementation of diets containing different levels of xylan for weaned piglets: Effects on growth performance and intestinal microecology. Chin. J. Anim. Nutr., 23: 1961-1969.

Yin, Y. and B. Tan, 2010. Manipulation of dietary nitrogen, amino acids and phosphorus to reduce environmental impact of swine production and enhance animal health. Int. J. Food Agric. Environ., 8: 447-462.

Yin, Y.L., C.M. Chen, H.Y. Zhong, R.L. Huang and X.S. Chen, 1994. Apparent digestibilities of energy, cell wall constituents, crude protein and amino acids of Chinese oil seed meals for growing pigs. Anim. Feed Sci. Technol., 45: 283-298.

Yin, Y.L., J.D. McEvoy, H. Schulze and K.J. McCracken, 2001a. Effects of xylanase and antibiotic addition on ileal and faecal apparent digestibilities of dietary nutrients and evaluating $\mathrm{HCl}$-insoluble ash as a dietary marker in growing pigs. Anim. Sci., 72: 95-103.

Yin, Y.L., J.D.G. McEvoy, H. Schulze and K.J. McCracken, 2000. Studies on cannulation method and alternative indigestible markers and the effects of food enzyme supplementation in barley-based diets on ileal and overall apparent digestibility in growing pigs. Anim. Sci., 70: 63-72.

Yin, Y.L., R.L. Huang, H.Y. Zhang, C.M. Chen, T.J. Li and Y.F. Pan, 1993. Nutritive value of feedstuffs and diets for pigs: 1. Chemical composition, apparent ileal and faecal digestibilities. Anim. Feed Sci. Technol., 44: 1-27.

Yin, Y.L., S.K. Baidoo, H. Schulze and P.H. Simmins, 2001b. Effect of supplementing diets containing hulless barley varieties having different levels of non-starch polysaccharides with $\beta$-glucanase and xylanase on the physiological status of gastrointestinal tract and nutrient digestibility of weaned pigs. Livest. Prod. Sci., 71: 97-107.

Yin, Y.L., S.K. Baidoo, J.L.L. Boychuk and H.H. Simmins, 2001d. Performance and carcass characteristics of pigs and broiler fed diets containing micronized barley, ground barley, wheat and maize. J. Sci. Food Agric., 81: 1487-1497.

Yin, Y.L., S.K. Baidoo, L.Z. Jin, Y.G. Liu, H. Schulze and P.H. Simmins, 2001c. The effect of different carbohydrase and protease supplementation on apparent (ileal and overall) digestibility of nutrients of five hulless barley varieties in young pigs. Livest. Prod. Sci., 71: 109-120. 